5. When an alcoholic solution of manganese tetrachuricie is diluted with a large volume of water, all the manganese is precipitater.

6. Manganese tetrachloride is probably the first product formed when manganese dioxide and hydrochloric acid interact.

[CONTRIBUTIONS FROM THE CHEAICAL LABORATORY OF THE CNIFERSITY OF CIXCINAATI, NO. $7 \mathrm{r}$.

\title{
ON THE NON-EXISTENCE OF $\beta$-CADMIUM IODIDE.
}

IYY J. I. SXELL.

Receiveri July 10,2907,

Among the specific gravities cletermined by Bödeker and published in his monograph, "Die Beziehungen zwischen Dichte und Zusammensetzungen bei festen und liquiden Stoffen" (Leipzig, i 860), that of cadmiun iodide was given as 4.576 . Fullerton having obtained a much higher result in this laboratory, F. IF. Clirke and F. A. Keb'er' in 1883 (also in this laboratory) determined the densities of specimens of the salt prepar d by a number of different methods. Portions prepared (a) by union of the elements in presence of water (b) by action of potassium iodide on cadminm sulphate with recrystallization from alcohol and (c) by action of hydriodic acid on cadmium carbonate (without removal of the free iodine present in the acid) gare results rarying between $5.6 \mathrm{I}$ and 5.73 at temperatures of $10.5^{\circ}$ to $18.2^{\circ}$; a slightly impure specimen prepared by heating equivalent quantities of the elements in an evacuated sealed tube gave 5.54 at $20^{\circ}$, a practically identical result. But portions prepared by the action of hydriokic acid on metallic cadminm and by the action of hydriodic acid on cadmium carbonate with the addition of metall c carminm to remove the coloration due to free iodine had specifiegravities of only 4.60 to 4.69 at $14.0^{\circ}$ to $19.0^{\circ}$-results almos as low as Bödeker's. From these results Clarke and Kebler inferred the existence of two fums of cadmiun iodicte, the common or $\alpha$-form and the form of low specific gravity, which they hesignated ficatminu iodicie. They pointed out that an extraordinary expansion is represented in the formation of cadnitum iodide of sp. gr. 4.63 (mean of all measurements), either from the $\alpha$-sait or from the elements, the respective molectlar volumes being: $\beta$-sait $79.2, \alpha x$-salt 64.8 , mean of elements 64.3 .

The present investigation was undertaken mith the object of determining more precisely the conditions of formation of $\beta$-cadminm iodide and of studying the relation of this substatice to the $\alpha$-salt. The latter question presented some interest, since there was, on the one hand, the possibility of a dimorphism, similar to that of mercuric iodicie and, on the other hand, a possibility of the one salt's being a polymer of the other, Hittorf's classical work on migration ratios having afforded evidence of the polymerization of calmium iodide in aqueous and alcoholic solutions. The 'Am. (h. J., 5, 235 (tos3). 
results of the research have, however, been such as to convince me that the bodies of low density, obtained by Clarke and Kebler, cannot have been pure cadmium iodide.

Only two specimens of the iodide were obtained by Clarke and Kebler and of only one of these was an analy sis published, though the other is described as "pure". The published analysis is not described in detail and the result ( $\mathrm{Cd}, 30.40, \mathrm{I}, 69.33$, total, 99.73) is not entirely satisfactory. The theoretical composition of cadmium iodide is : $\mathrm{Cd}, 30.68$ per cent., I, 69.32 per cent. Thus, while the quantity of iodine found was exactly theoretical, the quantity of cadmium was considerably less than the equivalent of the iodine-the discrepancy amounting to 0.9 per cent. of the cadmiun found.

$\beta$-cadmium iodide is described by Clarke and Kebler as brownish in color and as decreasing in weight and increasing in specific gravity on heating, three successive heatings to $50^{\circ}$ bringing the density up to $5.545, i$. e. almost to the normal value for $\alpha$-cadmium iodide. The loss of weight, which in one sample amounted to 5.5 per cent., is explained as "undoubtedly due to the formation of an oxide or oxyiodide with liberation of iodine". Yet the amount of insoluble material formed was "trifling". Now cadmium iodide (Mol. Wt. 366) in changing to cadmium oxide (Mol. Wt. I28) loses about two-thirds of its weight. A loss of 5.5 per cent. would, therefore, mean a transformation of 8.25 per cent. of the cadmium iodide into cadmium oxide with the formation of a quantity of oxide amounting to nearly three per cent. of the whole product--a portion that would hardly be described as trifling. If an insoluble oxyiodide were formed, the proportion of it in the heated product would be still greater. There remains only the possibility that a soluble oxyiodide was formed. Aside from the fact that no such compound is known, the quantity formed to correspond to a loss of iodine amounting to 5.5 per cent. of the original weight would be such that an analysis of the heated product wonld have readily revealed its presence. Thus, if the compound were $\mathrm{Cd}_{2} \mathrm{I}_{2} \mathrm{O}$, I 1.6 per cent. of the heated product would consist of oxyiodide and the analysis would yield 32.4 per cent. Cd instead of 30.7 per cent. and 67.2 per cent. I instead of 69.3 per cent. However, no analysis of the heated product appears to have been made.

The assignment of the formula $\mathrm{CdI}_{2}$ to this substance appears, there. fore, to have been made upon the strength of a single analysis, low in cadmium, and without an adequate examination of the properties and behavior of the substance itself.

The weakness of the evidence in favor of the existence of the $\beta$-salt not having been appreciated at the beginning of the present work, attempts to prepare the substance were at first confined to temperatures 
below $50^{\circ}$, since at this temperature, according to Clarke and Kebler, gradual transformation into the $\alpha$-form takes place. Cadmium iodide was prepared in a number of different ways, some involving, others not involving, the use of hydriodic acid. The specific gravity determinations were made at $30^{\circ}$, the work having been begun in midsummer, when it was inconvenient to work at lower temperatures. The powdered samples were placed in 10 to $25 \mathrm{cc}$. specific gravity bottles, covered with toluene and freed from air-bubbles by means of a filter pump before the remainder of the toluene was poured in. From 6 to $3 \circ \mathrm{g}$. of material was used with the $25 \mathrm{cc}$. and from 2 to $22 \mathrm{~g}$. with the ro cc. bottle. The specific gravity of the toluene used was determined by comparison with air-free water, a Sprengel-Ostwald pycnometer being used for this purpose. Products of specific gravity $30^{\circ} / 4^{\circ}$ of $5.60=0.02$ were obtained by preparation from (a) cadmium sulphate and potassium iodicle solutions, evaporated and extracted with alcohol (b) cadmium and iodine, digested under water (c) cadmium carbonate and hydriodic acid, decolorized by shaking with benzene (d) cadmium carbonate and hydriodic acid, decolorized by cadmium (e) cadmium oxide and hydriodic acid, decolorized by shaking with benzene. Equivalent quantities of iodine and caumium turnings, heated in a sealed tube one hour at $200^{\circ} \cdot 2.30^{\circ}$, did not react completely. The product, heated to fusion in a retort, yielded a distillate of iodine and left a button of $8 \mathrm{~g}$. cadmium in the mass of $57 \mathrm{~g}$. Of main product, which latter had a specific gravity of 5.50 , was grayish in color when powdered and left a slight insoluble residue of darker color when treated with either water or alcohol. The treatment of hydriodic acid with metallic cadmium, with evaporation at room temperature in vacuo or in air, yielded in one instance a product of high specific gravity, in others brownish products of slightly less than normal density, iti., 5.53 and 5.36 .

The work at room temperature having yielded nothing resembling $\beta$. cadmium iodide, experiments were now undertaken in which cadmium iodide was heated with hydriodic acid and crystallized by cooling. This procedure invariably yielded products of lower specific gravity than ordinary cadmium iodide. In some instances the density was only 0 . I or 0.2 lower than normal, in others it was as low as, or lower than, that of Clarke and Kebler's products. The products of very low specific gravity were all obtained in presence of metallic cadmium but I do not feel certain that its presence is essential. Some of them, $e . g$. preparations XXX and XXXIV presented a characteristic mossy appearance. None of the products of low specific gravity proved on analysis to be pure cadnium iodide.

These products, air-dried between filter papers, lost weight upon heating, the loss being, in general, greater the lower the specific gravity. One of them (XVII, sp. gr. 4.53), placed in a vacuum desiccator over phos. 
Products Resembling Clarke AND KebleR's $\beta$-CADMIUM Iodide.

\begin{tabular}{|c|c|c|c|c|c|c|}
\hline Number & Method of Prep & $\begin{array}{l}\mathrm{Gr} \\
30\end{array}$ & $\begin{array}{c}\text { Loss } \\
\text { on } \\
\text { Heating } \\
\text { Per Cent. }\end{array}$ & $\begin{array}{l}\text { Cadmium } \\
\text { Found } \\
\text { Per Cent. }\end{array}$ & $\begin{array}{l}\text { Iodine } \\
\text { Equivalent } \\
\text { of } \\
\text { Cadmium } \\
\text { Percent. }\end{array}$ & $\begin{array}{l}\text { Iodine } \\
\text { Found } \\
\text { Per Cent. }\end{array}$ \\
\hline VII & $\begin{array}{c}\mathrm{CdI}_{2}\left(\text { and a little } \mathrm{CdCO}_{3}\right) \\
\quad \mathrm{HI}+\mathrm{Cd} \ldots \ldots \ldots .\end{array}$ & 4.53 & 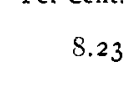 & \} & $63 \cdot 26$ & \\
\hline 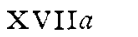 & . & 5 . & & & & \\
\hline & & & 2.95 & & 66.55\{ & \\
\hline $\mathrm{x}$ & $\mathrm{CdI}_{2}+\mathrm{HI}+\mathrm{Cd} \ldots \ldots \ldots$ & 3.93 & $\begin{array}{l}\text { (I) } 14 \\
(2) 15\end{array}$ & & $58 \cdot 5 \mathrm{I}$ & \\
\hline $\mathrm{xx}$ & XXX heated ............. & $\cdot$ & $\cdots \cdots$ & & $\cdots \cdots$ & $\ldots \ldots$ \\
\hline & $\begin{array}{l}\mathrm{XXX} \text { wa } \\
\mathrm{CdI}_{2}+1\end{array}$ & 4.9 & $\begin{array}{ll} & 6.23 \\
\text { (a) } 2.76 \\
\text { (b) } 2.70 \\
\text { (c) } 2.83\end{array}$ & $\left.\begin{array}{l}0 \\
6^{1} \\
33\end{array}\right\}$ & $\cdots \cdots$ & (a) \\
\hline $\mathrm{Va}$ & $\mathrm{XX}$ & 5. & $\ldots \ldots$ & . & & \\
\hline$x=2+2$ & $\ldots \ldots \ldots \ldots$ & $\begin{array}{l}5 \cdot 3 \\
\cdots\end{array}$ & $\begin{array}{l}\text { I. } 06 \\
\text { I.67 } \\
\ldots \ldots\end{array}$ & $\begin{array}{r}\cdots \cdots \\
30.68\end{array}$ & $\begin{array}{l}\ldots \ldots \\
\ldots \ldots \\
\ldots \ldots\end{array}$ & $\begin{array}{r}\cdots \cdots \\
69 \cdot 32\end{array}$ \\
\hline
\end{tabular}

phorus pentoxide, lost over 8 per cent. of its weight in the first 24 hours, and the desiccator, when opened, was found to contain hydriodic acid gas. The additional losses of weight on standing another 24 hours in the desiccator and on heating to $I 20^{\circ}$ were trifling. The residue was completely soluble in water. In another portion of the same preparation, which had been used in a specific gravity determination and thus washed with toluene and again air-dried, the loss under the same treatment was a little over 6 per cent. and, as before, was practically complete in 24 hours over phosphorus pentoxide in vacuo.

Determinations of cadmium and iodine were made in four of the products of low specific gravity, the cadmium being weighed as oxide, the iodine as silver iodide. The most important results obtained are given above in tabular form. In all cases the quantity of iodine was greater than the equivalent of the cadmium found. (As pointed out above, the same is true of Clarke and Kebler's analysis). Considerable differences were found in the iodine content of different portions of the same preparation (See especially XXVI and XXX), indicating that the preparations were not uniform. Microscopic examination showed that some of them contained dark globular masses attached to less strongly colored crystals, apparently ordinary cadmium iodide crystals, colored brown with free iodine. The mossy aspect noted in some of the specimens appears to be due to the arrangement of the cadmium iodide plates side by side with the edges vertical. The quantity of free iodine present in the preparations was found to be extremely small, one drop of $\mathrm{N} / \mathrm{I}$ o thiosulphate solution sufficing to decolorize the solution of $0.3035 \mathrm{~g}$. of preparation XVII. Yet free iodine could be smelled and in some cases even ${ }^{1}$ Duplicate analyses of one sampled portion. 
seen in bo:tles in which the bodies of low specific gravity had been stand. ing for a few weeks. A determination of cadminu in the residue from the hating of one of the specinens (XVII) to $100^{\circ}-120^{\circ}$ and one of iodine in a simiar residne from another specimen (XXXIV) gave: $\mathrm{Cd}, 30.56, \mathrm{I}, 69.25$, showing that the honles are converted by heating into cadnium iodide (Theory C.1, 30.65, I, 69.32) without any appreciable formation of oxide or oxyiodide.

From these results the inference is unavoidable that these bodies of low specific gravity (which coincide in method of formation and in behavior with those of Clarle and Kebler) consist of cadmium iodicle. containing more or less hydriodic acid and water, together with a trace of free iodine. Whether they are merly cadminm iolide crystals, ret with hydriodic acid solution or contain the hydrogen iodide in solid solution or in chenical combination with a part of the cadnium iodide is not clear. By cooling to $-25^{\circ}$ a solution of cadmium iodide in saturated hydriodic acid, Berthelot obtained crystals which he believed to comprise a compound of hydriodic acid with cadmium iodicle, but this substance was dissociated at roon temperature and for that reason could not be isolated. Drying on a porous plate yielded a yellowish, anliydrous(?). crystalline substance, containing 5.3 per cent. of lyydriodic acid. He also noted that cadnium iodide crystals absorb an appreciable quantity of hydriodic acid gas. I think it probable that the hydrogen iodide is contained in the cadminu iodide crystals in the form of a solic solution and, retaining its affinity for water, causes the absorption of water into the crystals.

In the course of this investigation I have twice observed that, when several crops of crystals are taken from a solution containing hydriodic acid, the later crops are whiter than the earlier but become dark on long standing. From this it would appear that the cadninum iodide is capable of dissolving free iodine as well as hydrogen iodide.

Bödeker, in his specific gravity determinations, aroided the use of powders and he explicitly states that in some instances he fused his compounds in the apparatus used as a pycnometer. This stggested the possibility of the formation of a modification of cadnium iodide of low specific gravity at some temperature higher than the boiling point of hydriodic acid solution. Although my own observations and those of Clarke and Kebler with cadmium iodide prepared from the elements by heating in a sealed tube iudicated the contrary, it was thought worth while to repeat Bödeker's experiment. Io grams of the salt were fused in a porcelain crucible and poured out into a porcelain dish. Apparently, a little oxidation occurred in the process of fusion and the cooled product was silur gray in color. A portion of this in mass, covered with toluene and

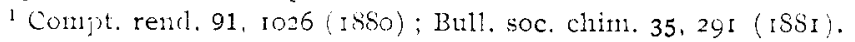


freed from air by pumping, gave a specific gravity of 5.335 but a powdered portion gave 5.60. There thus appears no evidence of the existence of a second solid form of cadmium iodide, even at higher temperatures.

\section{Summary.}

I. By crystallizing cadmium iodide from solutions in hydricdic acid, products of low specific gravity, in all respects similar to the so-called " $\beta$-cadmium iodide," were obtained. On analysis these were found to contain hydriodic acid and water in addition to cadmium iodide.

2. A critical examination of Clarke and Kebler's work leads to the conclusion that there is no valid evidence of the existence of a form of cadmium iodide of lower specific gravity than 5.6.

\section{SOME REACTIONS DURING WATER TREATMENT.'}

BY EDWARD BARTOW AND J. M. LINDGREN.

Received July 8, I907.

The necessity for a treatment to improve the University of Illinois Water Supply is shown by a variety of unsatisfactory features viz : turbidity forming on exposure to the air; sediment varying in color from black to red according as the amount of oxidation of the iron salts varies; trouble from crenothrix in the mains; soft scale, clogging the feed pipes of boilers and trouble in dairying and photography. The Champaign and Urbana city water which is drawn from the same geological forma. tion, has the same drawbacks and also causes incrustation in tea-kettles and the clogging of water backs in ranges and furnaces.

In attempting to improve the water by removing the carbonates of calcium and magnesium, the amounts removed did not correspond to our calculations. Analysis of the water had been made gravimetrically and also by the briefer methods suggested by the American Public Health Association. The results of the former analysis are as follows.

ANALYSIS OF WATER FROM UNIVERSTTY OF ILI,INOIS WATHR SUPPLY.

\begin{tabular}{|c|c|c|c|c|c|}
\hline Ions & $\begin{array}{l}\text { Parts per } \\
\text { Million }\end{array}$ & \multicolumn{2}{|c|}{ Hypothetical Combinations } & $\begin{array}{c}\text { Parts Per } \\
\text { Millions }\end{array}$ & $\begin{array}{l}\text { Grains } \\
\text { Iert. s } \\
\text { Gallons }\end{array}$ \\
\hline Potassium, $\mathrm{K}$ & 2.6 & Potassium nitrate, & $\mathrm{KNO}_{3}$ & 1.1 & 0.06 \\
\hline Sodium, $\mathrm{Na}$ & 29.0 & Potassium chloride, & $\mathrm{KCl}$ & 2.9 & 0.17 \\
\hline Ammonium, $\mathrm{NH}_{4}$ & 2.3 & Sodium chloride, & $\mathrm{NaCl}$ & 3.5 & 0.20 \\
\hline Magnesium, Mg, & 34.9 & Sodium sulphate, & $\mathrm{Na}_{2} \mathrm{SO}_{4}$ & 3.6 & $0.2 \mathrm{I}$ \\
\hline Calcium, Ca & 70.1 & Sodium carbonate, & $\mathrm{Na}_{2} \mathrm{CO}_{3}$ & 60.5 & 3.52 \\
\hline Iron, Fe & 1.0 & Ammonium carbonate, & $\left(\mathrm{NH}_{4}\right)_{2} \mathrm{CO}_{3}$ & 6. I & 0.36 \\
\hline Aluminium, Al & I. 3 & Magnesium carbonate, & $\mathrm{MgCO}_{3}$ & 121.2 & 7.07 \\
\hline Nitrate, $\mathrm{NO}_{3}$ & .7 & Calcium carbonate, & $\mathrm{CaCO}_{3}$ & $\mathrm{I} 75.2$ & 1022 \\
\hline Chlorine, $\mathrm{Cl}$ & 3.5 & Iron carbonate, & $\mathrm{FeCO}_{3}$ & 2. I & 0.12 \\
\hline Sulphate, $\mathrm{SO}_{4}$ & 2.3 & Alumina, & $\mathrm{Al}_{2} \mathrm{O}_{3}$ & 2.5 & 0.15 \\
\hline Silica, $\mathrm{SiO}_{2}$ & 18.9 & Silica, & $\mathrm{SiO}_{2}$ & I 8.9 & I. 10 \\
\hline & & & & 397.6 & 23.18 \\
\hline
\end{tabular}

\footnotetext{
${ }^{1}$ Read at the Toronto Meeting of the American Chemical Society,
} 